\title{
Application of digital photography in biomechanical studies of osteosynthesis systems
}

\author{
M.S. Shidlovskiy • O.P. Zakhovajko • M.M. Dyman \\ Igor Sikorsky Kyiv Polytechnic Institute, Kyiv, Ukraine
}

Received: 05 March 2018 / Accepted: 15 March 2018

\begin{abstract}
Purpose. The subject of this work is the experimental substantiation of the contactless method of measuring the movements of bone fragments with the help of digital photography.

Design/methodology/approach. During the experiment limbs were used without pathology of bone tissue and tumors on bone tissue. Fixation of bone fragments (osteosynthesis) is performed with the aid of different devices of external fixation. Loading methods: compression, bending and cyclic loading, which simulate the weight of a person.

Results. A comparison of the results obtained confirmed the suitability of the method for measuring the displacement of bone fragments with the help of digital photography for practical use.

Originality/cost. Results are important for medicine and can improve treatment.
\end{abstract}

Keywords: means of osteosynthesis, movement of fragments of bones, rigidity of fixing fractures, measuring movements, digital photography, suitability of the method.

Introduction. Means of osteosynthesis (OS) should provide reliable fixing of bone fragments, maximally preventing their mutual displacement in the process of transportation and treatment of patients. OS means any system used to fix bone fragments, that is, a complex of "bone fragments - a means for fixing a fracture." Under deformations we will understand not only the absolute displacements of the points of the system of the OS, but also the mutual displacement of adjacent points of the debris of the bone directly at the fracture.

If to use purely mechanical approaches, processes of deformation of OS systems do not differ from the processes of deformation in any objects studied in the mechanics of a deformed body: the effect of external forces and moments of these forces - the influence of concomitant factors - the result in the form of deformations and displacements.

In most of the experiments in the experimental biomechanics of the OS, in particular [1-3], only static (one-time) loads were considered. However, as practice shows, multiple loads lead to higher levels of deformation and displacement at the fracture site. Destruction can occur at lower loads than with one-off actions.

As a rule, objects of biological origin, which are experimentally investigated (bones with simulated fractures, means of fixing fractures, etc.), have a rather complex form, and the movement of individual points occurs in different directions. The determination of the displacements of the set of points of these objects using conventional technical means (mechanical indicators of displacement, calipers, micrometers, etc.), as well as optical methods (instrumental microscopes, cathetometers), in some cases, is practically impossible. The use of modern digital photo and video equipment in biomechanical research is the most suitable and universal way of solving many technical problems of registration of displacements and deformations of anatomical objects under the influence of loads [4].

In the laboratory of biomechanics of the department of dynamics and strength of machines and resistance materials KPI named after Igor Sikorsky was designed and implemented a practical method of measuring the displacement of human bone fragments in an experiment. This method, using digital photography, records the values of displacement of bone fragments with osteosynthesis systems under the influence of external loads. At the same time, it is proposed to measure the displacement according to the labels directly established at the controlled points in the fracture zone [5] and analytically at the positions of the reference points outside the fracture zone [6].

The aim of the research was to develop a new, more advanced, when compared with the known method of registration and analysis of the magnitude of displacement of bone fragments in modern OS systems. On the basis of the application of these methods, it was possible to conduct photo and video shooting of test objects and non-contact methods at given load modes to study the processes of deformation of OS systems. In this case, the characteristics of the rigidity

$\triangle$ M.S. Shidlovskiy n_shidlovsky@ukr.net
O.P. Zakhovajko zakhov1911@gmail.com
M.M. Dyman mrs_d@ukr.net 
of the systems "bone - fixing apparatus" are determined in real, including cyclic, modes of action of external loads under compression, bending and torsion. According to these data, the most dangerous types of loads on damaged bones are determined and optimal OS systems are selected, which provide the permissible levels of mutual displacement of bone fragments.

In our previous studies [4] we measured: 1. general deformation of the test specimen (movement of the point of application of the load relative to the place of bone fixation); 2 . the displacement of one point of the fracture relative to the place of attachment of the bone; 3. mutual displacement of two adjacent points of a fracture.

In the first case, the total deformation of the system is measured by means of a motion sensor mounted on the test vehicle. Therefore, in this case, the general deformation consists of deformations of the means of fixation, deformation of the bone and deformation of the load system. Reciprocal movement of system points in this approach is very difficult to detect.

In the second case, the movement was measured using the clock indicator. Clock-type indicators, along with high reliability and ease of handling, are relatively large in size. The indicator foot creates an additional load on the sample, which may lead to distortion of measurement results. The displacement of one point may not correlate at all with the mutual displacements of other points of the fracture (convergence of some points of fracture to load and difference of other points).

In the third case, the measurements were made using a catheter. Since the operating position of the cathetometer B-630 is vertical, it was used exclusively for measuring vertical movement of preparations during loading. This approach does not guarantee that we have correctly selected the most dangerous points with the greatest mutual offsets.

An advanced method is suggested. This is a simultaneous determination of the linear displacements of several fracture points in the longitudinal and transverse directions.

Since it is not possible to consider a large number of points, it is proposed to limit to the four points of the fracture: the point closest to the fixation means (plate or external fixation apparatus); point, the most distant from the fixture; two points, the most distant from the line connecting the first two points. From these points we choose the point with the greatest displacements. Moreover, in addition to linear, angular displacements are also recorded.

Objects of research. Bone preparations of people were used, which were taken from the biomaterial of amputated limbs to be disposed of and which, according to the order of Ministry of Health of Ukraine No. 325 of 08.06.2015, were disposed of after the end of the tests. For the experimental study, bones were used without pathological changes. On the bones artificially created the necessary fractures with the help of Langenbeck saw. Fractures were fixed by various means of fixing fractures by conventional surgical methods.

The essence of the method. The basis of the proposed method is the measurement of the displacement of any points of bone debris in the fault zone using reference elements (labels) installed on external fracture sites without the need to measure the displacements of internal fracture sites and the possibility of applying analytical methods to determine these displacements.

Measurement consists of the following sequence of actions:

1) fixing to the desktop of a testing machine a test bone with a model fracture, a system for fixing the damage and reference elements pre-placed on chips;

2) photographing a calibrated object of known size for the establishment of a scale factor;

3) photographing the fracture site of undisturbed bone; In the future, this scene is used as a control;

4) application to the object of loading, which leads to the appearance of displacements in the gap zone;

5) photographing the bone, which is subject to loading, without changing the position of the fixed part of the bone and device; photographing;

6) processing of digital photographs, determining the distances between the supporting elements in the undeformed system and the system under the influence of the load;

7) calculation of displacement at different points of the gap zone.

Stages 1-5 are described in detail in our papers [4, 7, 8]. In this article only the features of the measurement methodology concerning the study of fracture fixing systems are given.

To explain further actions, fig. 1 is used, which shows the gap between the ankle bone and the fixation system [9] in the uncharged state (Fig. 1a) and after loading (Fig. 1b). In fig. 1c, g - a simplified bone structure with a fracture in the initial state and under the action of the load.

Stage 1. On the test bench, a test specimen was fixed to the sample with pre-installed reference elements (labels) on it.

The specified $5 \times 5 \mathrm{~mm}$ frame elements were made of $0.5 \mathrm{~mm}$ white-colored PVC sheet. On the surfaces of the elements, the sharpened scalpel affects the perpendicular trias that formed the intersection. The risks were filled with black paint to increase contrast. As practice has shown, such intersections allow accurately carry out further computer image processing on the PC display.

Before installing a bone, a device for creating digital images, such as a digital camera, is placed in parallel with the plane in which the reference elements on the prototype are located. In this case, all labels should be in the focus of the lens and be centered. 


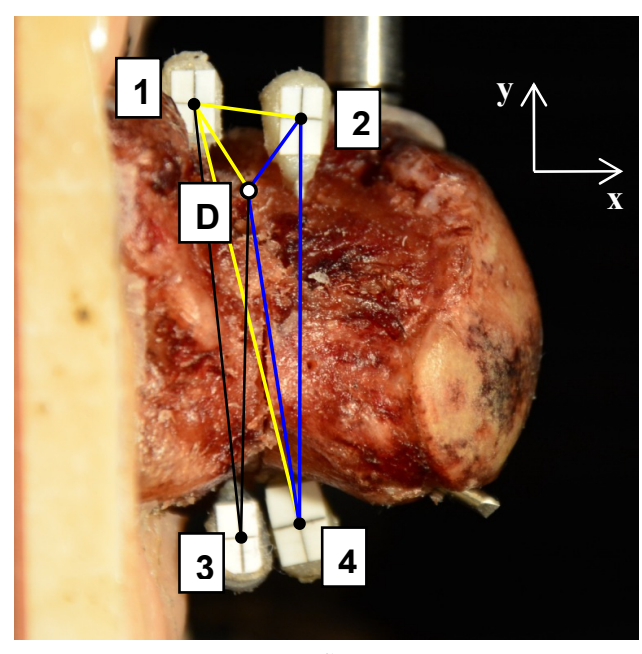

$a$

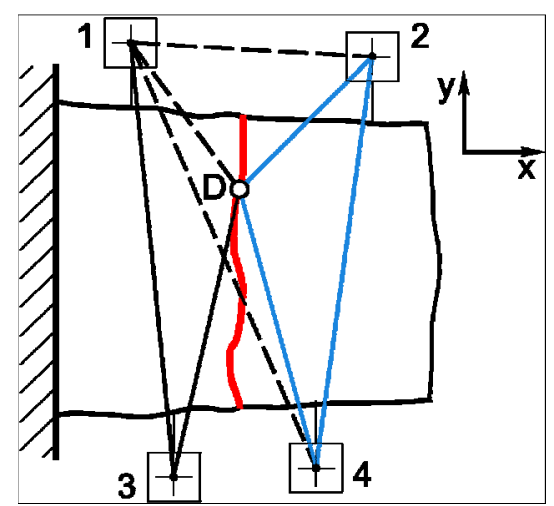

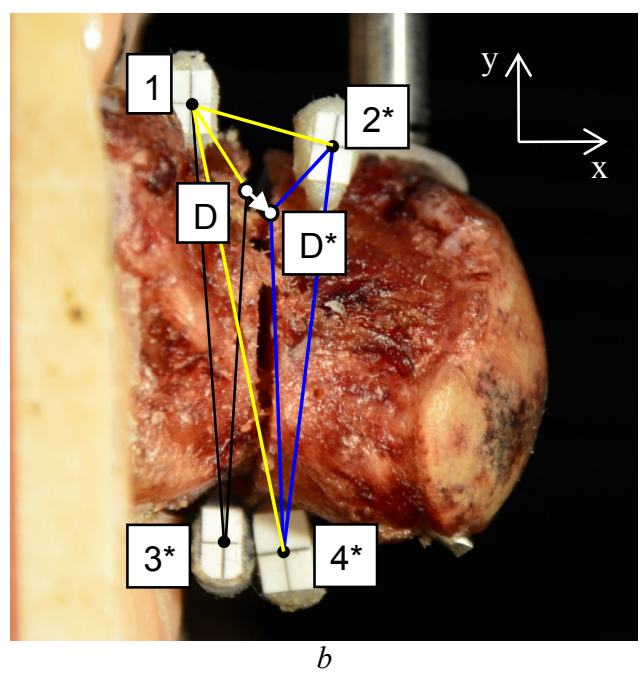

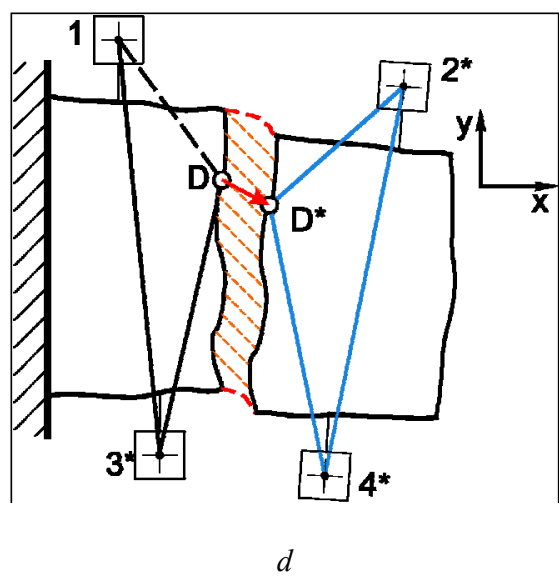

Fig. 1. Ankle bone with fracture (a, b) and deformation scheme (in, g): unloaded (a, c) and loaded (b, g) samples; $1,2,3,4$ - reference elements installed on bone debris; $D$ and $D *$ are adjacent points of the bone fragments, for which the bias was determined

Stage 2. A calibrated element (Johansson reference tile or other object of known size) was placed on the same level with the reference elements. In this case, the edges (faces) of the element should be clear and located strictly horizontal. In fig. 1 this calibrated element is not shown.

The magnitude of the received image was found in the manner described in [5]. Images were transferred to a computer and using any digital image processing program (for example, FastStone Image Viewer. ACDSee Pro or Paint determined the size of the Johansson tile in pixel, from which the scale factor of the received image was calculated using the formula $\mathrm{M}=\mathrm{n} / \mathrm{h}$, (pixel / $\mathrm{mm}$ ), where $\mathrm{n}$ is the number of pixels corresponding to the height of the Johansson tile; $\mathrm{h}$ - actual height of Johanson's tile in mm.

Stage 3. The simulated fracture and fixation bone was photographed and the image was used as a control nondeformed sample (Fig. 1a, c).

Stage 4. The investigated bone was loaded with a pre-selected load, which did not lead to the destruction of the "bone - fixation tool" system, but only caused a reciprocal movement into parts of the fracture.

Stage 5. Again, the system was photographed in a deformed state under the action of a given load (Fig. 1b, g).

Stage 6. The received images have been processed. Initially, on both pictures, the distances between the reference elements were measured. The ends of the vector segments on the computer display screen were combined with the corresponding reference elements and the projections of these vectors on the vertical and horizontal axes in pixel were determined (Fig. 2). Then, using the scale factor, the values of distances in real units of length (in millimeters) were counted.

Stage 7. Based on the results of measuring the distances between the reference elements of the object in the undeformed and deformed states, the magnitudes of mutual displacements (displacements) of individual points in the fracture region were calculated. This step will be described in more detail.

To find the displacement of any point of the fracture under the action of the load, both parts of the bone were considered to be absolutely solid (their deformations were negligibly small compared with the magnitude of the mutual displacement in the fracture). 


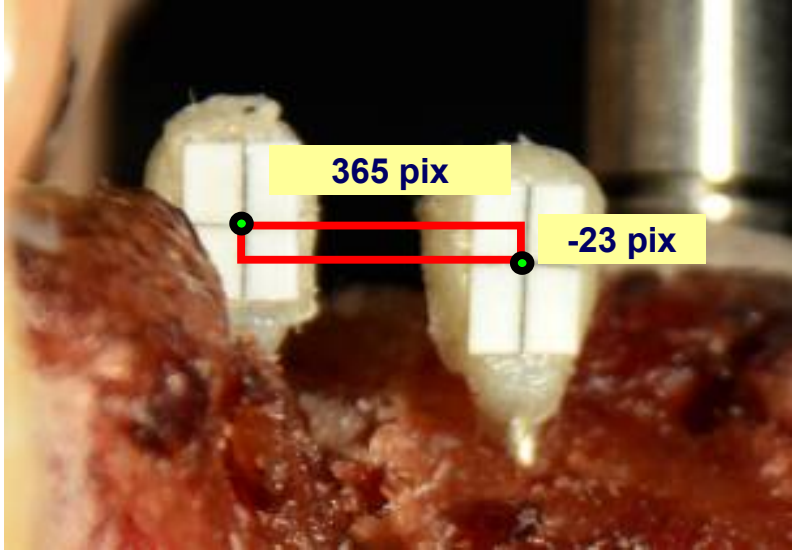

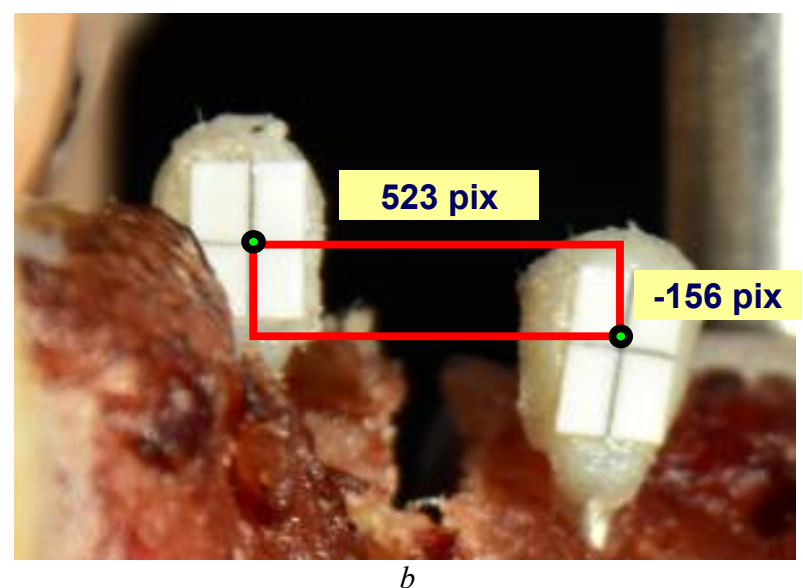

Fig. 2. Scheme for determining the mutual position of reference points to load (a) and after loading (b) using digital photography

Since at any point D (Fig. 1a, c) the ramp is not installed, its coordinates after displacement in the system, associated with the point 1 , we will find analytically, considering this point as the third vertex of the rigid triangle $\Delta$ $\left(2 * 4 * D^{*}\right)$ (Fig. $\left.1 b, d\right)$ by the known coordinates of two other vertices $2 *$ and $4 *$.

The sequence of actions is as follows.

- in the fracture zone the point D is selected (Fig. 1a, c), the displacement of which must be determined;

- in the manner described above, we found the coordinates of the points 2 (X2, Y2), 4 (X4, Y4) and D (XD, Y4) in the coordinate axes system, the beginning of which is combined with the point 1 (Fig. 1);

- then we found the lengths of the sides L2-D and L4-D of the triangle $\Delta(2-4-D)$ at the known lengths of their projections on the $\mathrm{X}$ and $\mathrm{Y}$ axis:

$$
\begin{gathered}
L_{2-D}=\sqrt{\left(X_{2}-X_{D}\right)^{2}+\left(Y_{2}-Y_{D}\right)^{2}} ; \\
L_{4-D}=\sqrt{\left(X_{4}-X_{D}\right)^{2}+\left(Y_{4}-Y_{D}\right)^{2}} .
\end{gathered}
$$

After loading the sample with force $\mathrm{P}$, which is applied to the bone fragments not fixed in the fixator, this fragment is shifted relatively to the fixed time of the bone (Fig. 1b, g). Since the displacement of bone fragments is much larger than possible deformations under the action of the load, then these fragments, and hence the related triangles, should be considered absolutely rigid.

In the future, the following actions were carried out:

- After applying the load, the sample was again photographed and new coordinates of the points $2^{*}\left(\mathrm{X}_{2^{*}}, \mathrm{Y}_{2^{*}}\right)$ and $4^{*}\left(\mathrm{X}_{4 *}, \mathrm{Y}_{4 *}\right)$ on the free part in the coordinate system associated with the point 1 were set;

- the coordinates of the point $\mathrm{D}^{*}$ were found as the coordinates of the third vertex of the triangle $\Delta\left(2 * 4 * \mathrm{D}^{*}\right)$, provided that the lengths of the sides of the triangle under load do not change:

$$
\begin{aligned}
& L_{2 *-D^{*}}^{2}=L_{2-D}^{2}=\left(X_{2 *}-X_{D^{*}}\right)^{2}+\left(Y_{2 *}-Y_{D_{*}}\right)^{2} ; \\
& L_{4 *-D^{*}}^{2}=L_{4-D}^{2}=\left(X_{4 *}-X_{D^{*}}\right)^{2}+\left(Y_{4 *}-Y_{D^{*}}\right)^{2} .
\end{aligned}
$$

We set the coordinates of points based on their sign, considering the coordinate system $\mathrm{X}$ and $\mathrm{Y}$ with the beginning at the point 1 as the right.

Received A system of square equations was received with respect to the coordinates of the point $\mathrm{D}^{*}$. The solution of this system is two groups of roots $\left(\mathrm{X}_{\mathrm{D}^{*}}, \mathrm{Y}_{\mathrm{D}^{*}}\right) 1$ and $\left(\mathrm{X}_{\mathrm{D}^{*}}, \mathrm{Y}_{\mathrm{D}^{*}}\right)$ 2. Those values were accepted that do not contradict the real position of the point $\mathrm{D}^{*}$ with respect to the points $2^{*}$ and $4 *$.

The position of the point $\mathrm{D}$ on the fixed part of the bone is found by moving the triangle $\Delta$ (1-3-D) from Fig. 1a, in Fig. 1b, g.

Points D and $\mathrm{D}^{*}$ are joined by a segment which in magnitude and direction meets the vector of the desired moving point $\mathrm{D}$. The value of this displacement is from the expression:

$$
\Lambda_{D}=\sqrt{\left(X_{D^{*}}-X_{D}\right)^{2}+\left(Y_{D^{*}}-Y_{D}\right)^{2}} \text {. }
$$

The proposed method makes it possible to determine the displacement of any kind of bits of fragments in the fracture zone, and the use of analytical methods for processing results using computer programs can significantly increase the amount of useful information received from the experiment and increase the productivity of research.

In order to assess the suitability of this method, the data obtained by the method of digital photography, compared with the data obtained by direct measurement of displacements by contactless method using an optical system, for example, using a catheter, and the accuracy of the proposed method is estimated. 
For tests, the tibia with a simulated direct fracture in the diaphyseal region and a rod device of external fixation [4] with pre-installed reference elements on it with all the requirements provided for in stage 1 (fig. 3) was applied. On one level with the reference elements a Johansson calibrated tile $20 \mathrm{~mm}$ high placed on a digital image of which the scale factor $\mathrm{M}$ was determined (stage 2). The bone sample was photographed (Step 3, Figure 4a), and the image was used as a control.

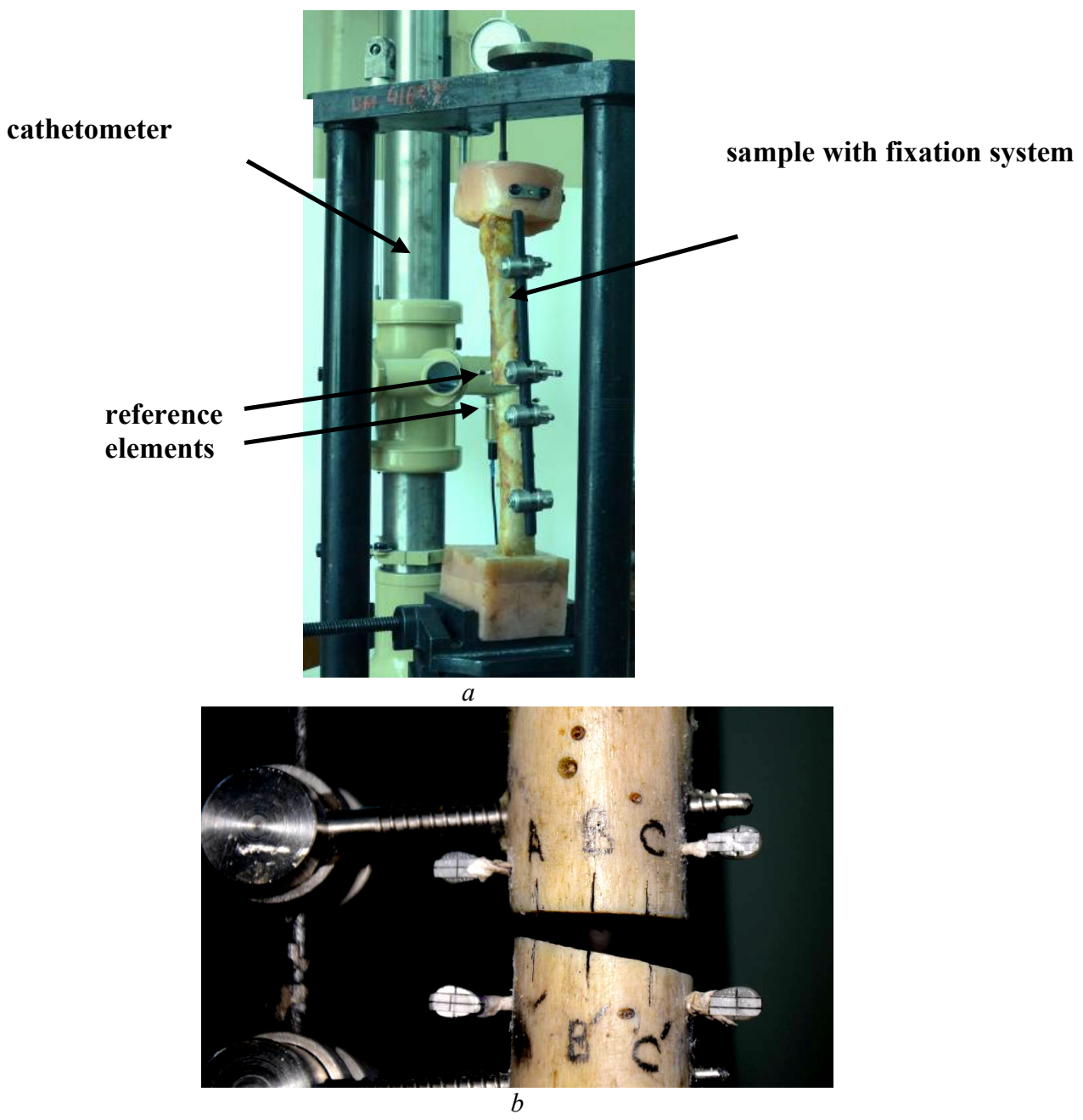

Fig. 3. Testing device (a) and sample of the tibia with simulated fracture fixed by the rod apparatus of external fixation and with the established reference elements (b): $A, A^{\prime}, B$. $B^{\prime}, C, C^{\prime}$ - control points
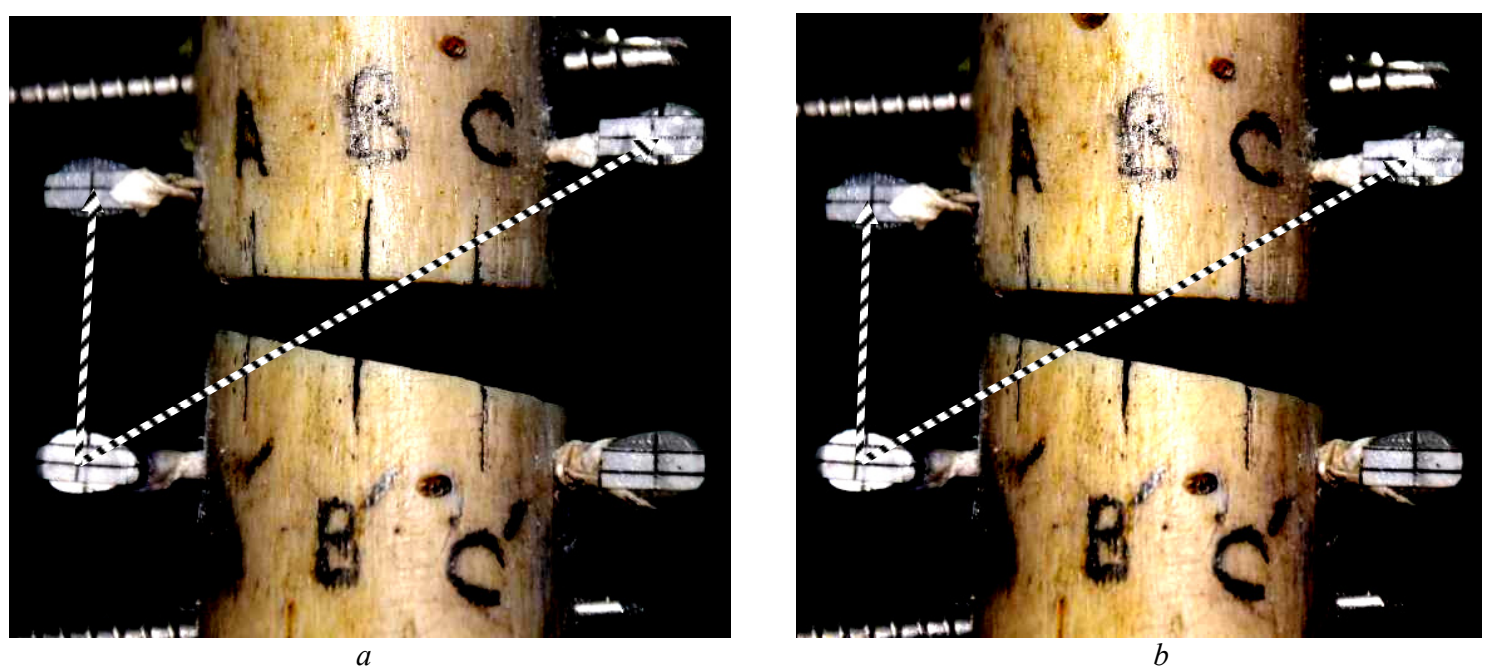

Fig. 4. Scheme for determining the mutual position of reference points to (a) and after (b) loading using digital photography

The sample was then photographed in a deformed state under the action of loading (steps 4-5). Measuring the displacements in pixel was carried out using the standard software for processing the digital images, MS Paint (step 6). 
The ends of the vector-segment segments were combined with the corresponding reference elements and determined the projections of these vectors on the vertical and horizontal axes (Figs 4a, b). The difference between the projections in the undeformed and deformed states was determined by the displacement of the reference elements in the corresponding directions (step 7).

In this way, the points whose movement were determined were pre-labeled with the labels directly on the sample (points A, A', B, B', C, $\mathrm{C}^{\prime}$ in Fig. 4). This method allows you to determine the offset by the labels in the predefined points in the fracture zone. The number of labels applied is limited to the size of the sample.

In order to assess the accuracy of the proposed methods for determining displacements, in addition to photographing the specimen, measurements of point displacements in the fracture zone were carried out using a cathetometer B-630 (Fig. 3a). In parallel with photographing the sample in unloaded and deformed states, the vertical distances between the three control points of the fracture (distances A-A', B-B , C-C $\mathrm{C}^{\prime}$ in Figs $3 \mathrm{~b}$ and 4 ) and reference points 1-4 were measured. 20 measurements of displacement were carried out.

Results of measurements and calculations are presented in Table. 1. The table shows the results of measurements of the displacements of the points of the fracture and the rapping points, as well as the measurements data using a cathetometer (in brackets). The maximum deviation of the results of the measurement by digital photographic processing from the data of control measurements by a cathetometer does not exceed $0.040 \mathrm{~mm}$. The average deviation is $0.020 \mathrm{~mm}$.

Movement at the fracture site of the tibia with a rod device of external fixation under a load of $200 \mathrm{~N}$

Table 1

\begin{tabular}{|c|c|c|c|c|c|}
\hline \multirow{2}{*}{$\begin{array}{c}\text { No. of } \\
\text { trial }\end{array}$} & \multicolumn{3}{|c|}{ Break points } & \multicolumn{2}{c|}{ Reference points } \\
\cline { 2 - 6 } & $\mathbf{A}-\mathbf{A}^{\prime}$ & $\mathbf{B}-\mathbf{B}^{\prime}$ & $\mathbf{C}-\mathbf{C}^{\prime}$ & $\mathbf{1}-\mathbf{3}$ & $\mathbf{2}-\mathbf{4}$ \\
\hline $\mathbf{1}$ & $0.99(0.97)$ & $1.09(1.11)$ & $1.24(1.26)$ & $0.72(0.71)$ & $1.41(1.44)$ \\
\hline $\mathbf{2}$ & $1.00(1.01)$ & $1.20(1.17)$ & $1.29(1.33)$ & $0.75(0.75)$ & $1.50(1.53)$ \\
\hline $\mathbf{3}$ & $0.94(0.92)$ & $1.13(1.12)$ & $1.27(1.29)$ & $0.73(0.72)$ & $1.53(1.53)$ \\
\hline $\mathbf{4}$ & $1.01(1.03)$ & $1.22(1.18)$ & $1.28(1.31)$ & $0.75(0.73)$ & $1.53(1.57)$ \\
\hline $\mathbf{5}$ & $1.02(1.00)$ & $1.23(1.26)$ & $1.29(1.30)$ & $0.80(0.79)$ & $1.50(1.51)$ \\
\hline
\end{tabular}

Note: the numbers in parentheses are the results of the measurement with the B-630 cathetometer

The data of comparing the results of the measurements of the displacement of the point $\mathrm{B}$ with respect to point $\mathrm{B}$ and calculations are presented in the table. 2. Table shows the results of measurements using a cathetometer (the second column in the table), based on the results of the measurements of the displacement of the reference elements and the subsequent calculations (the third column), as well as the results of measuring displacements directly by digital images without application reference elements (last column in the table). The relative difference between the calculated data, the results of direct measurements and control results (cathetometer) does not exceed $3.41 \%$ and $3.38 \%$ respectively.

Table 2

Results of measurements and calculations of displacements of the point $B^{\prime}$ relative to the point $B$ in the fracture zone

\begin{tabular}{|c|c|c|c|}
\hline \multirow{3}{*}{$\begin{array}{l}\text { No. of } \\
\text { trial }\end{array}$} & \multicolumn{3}{|c|}{ Vertical displacement of the control point, $\mathrm{mm}$} \\
\hline & \multirow{2}{*}{$\begin{array}{l}\text { Measurement with } \\
\text { cathetometer B-630 }\end{array}$} & \multicolumn{2}{|c|}{ Digital photography } \\
\hline & & $\begin{array}{c}\begin{array}{c}\text { Calculation using reference } \\
\text { elements }\end{array} \\
\end{array}$ & $\begin{array}{c}\text { Measure directly by the } \\
\text { labels in the photo }\end{array}$ \\
\hline 1 & -1.11 & $-1.09(-1.80)$ & $-1.09(-1.80)$ \\
\hline 2 & -1.17 & $-1.21(+3.41)$ & $-1.20(+2.56)$ \\
\hline 3 & -1.12 & $-1.15(+2.67)$ & $-1.13(+0.89)$ \\
\hline 4 & -1.18 & $-1.19(+0.85)$ & $-1.22(+3.38)$ \\
\hline 5 & -1.26 & $-1.27(+0.79)$ & $-1.23(-2.38)$ \\
\hline
\end{tabular}

Note: the minus sign means that the distance between the points $B^{\prime}$ and $B$ is reduced, the numbers in brackets are the error in percentages

The standard of ISO/IEC 17025 [10], with the implementation and subsequent use of any method for measuring physical quantities, provides for an estimation of uncertainty of measurements. Using the proposed method [11], uncertainty of measurements of linear sizes of samples was calculated using a cathetometer B-630. 
Taking into account all sources of uncertainty, the model equation has the form:

$$
l=l_{0}+\Delta_{o}+\Delta_{\hat{a} e i ̀}+\Delta_{t},
$$

where the input values: $l$ - the size being measured; $l_{0}$ - readings of a catheter at $20^{\circ} \mathrm{C} ; \Delta_{o}$ - error of operator readings; $\Delta_{\text {rand }}$ - error due to the action of random factors; $\Delta_{t}$ - possible change in size due to deviation of temperature from $20{ }^{\circ} \mathrm{C}$.

The budget of uncertainty [11] of a catheter is shown in Table. 3. According to the calculations, the variance of values that can be sufficiently substantiated from the prescribed measuring value lies in the range of $\pm 0.026 \mathrm{~mm}$.

Table 3

The uncertainty budget of the B-630 cathetometer

\begin{tabular}{|c|c|c|c|c|c|c|}
\hline Input value & $\begin{array}{c}\text { Estimate of the } \\
\text { input value, } \mathrm{mm}\end{array}$ & $\begin{array}{c}\text { Standard } \\
\text { uncertainty, } \\
\mathrm{mm}\end{array}$ & $\begin{array}{c}\text { The number } \\
\text { of degrees } \\
\text { of } \\
\text { independen } \\
\text { ce }\end{array}$ & $\begin{array}{c}\text { Probability } \\
\text { distribution }\end{array}$ & $\begin{array}{c}\text { Sensitivity } \\
\text { ratio }\end{array}$ & $\begin{array}{c}\text { Contribution } \\
\text { to uncertainty, } \\
\text { mm }\end{array}$ \\
\hline$l_{0}$ & 25 & 0,00866 & $\infty$ & Equiprobability & 1 & 0,00866 \\
\hline$\Delta_{o}$ & 0 & 0,00144 & $\infty$ & Equiprobability & 1 & 0,00144 \\
\hline$\Delta_{\text {sun }}$ & 0 & 0,00803 & 19 & Normal & 1 & 0,00803 \\
\hline$\Delta_{t}$ & 0 & 0,00590 & $\infty$ & Equiprobability & 1 & 0,00590 \\
\hline$l$ & $\mathbf{2 5}$ & $\mathbf{0 , 0 1 3 4}$ & $\mathbf{1 4 4}$ & $U(l)=\mathbf{0 , 0 2 6} \mathbf{M M ,} p=0,95, k(p)=1.99$ \\
\hline
\end{tabular}

Taking into account the average deviations of the photographic recording of the displacement results from the control measurements by the cathetometer $(0.020 \mathrm{~mm})$, we establish the final uncertainty value of the proposed method in the range of $\pm 0.046 \mathrm{~mm}$.

\title{
Conclusions
}

The proposed method for measuring displacements of bone fragments by means of digital photography allows simultaneously to perform measurements in different planes and at different points, which significantly increases the amount of information about moving points of the experimental object. At the same time, the accuracy of measurements does not decrease compared with traditional measurement methods.

The method differs from the traditional ones in that, when it is used, there is no contact between the measuring apparatus and the object under study, which does not lead to additional deformations.

The result of the comparison showed the suitability of the digital photography method as a direct measurement of the labels established at the points under study and by the analytical method at positions of reference points outside the fracture zone. The difference with the data obtained with the cathetometer was within the limits of the measurement equipment error and did not exceed $3.4 \%$ of the measured value.

\section{Застосування цифрової фотозйомки в біомеханічних дослідженнях систем остеосинтезу}

\author{
М.С. Шидловський, О.П. Заховайко, М.М. Димань
}

Анотація. Запропонований та експериментально обтрунтований безконтактний метод вимірювання зміщень уламків кісток за допомогою иифрового фотографування. Описана методика як безпосереднього вимірювання переміщень за мітками, встановленими в досліджуваних точках в зоні перелому, так і аналітичним методом за положеннями реперних точок поза зоною перелому. Наведені результати вимірювань переміщень запропонованим методом та традиційним з використанням катетометра. Зіставлення отриманих результатів підтвердило ефективність методу вимірювання зміщень уламків кісток за допомогою иифрового фотографування для практичного застосування.

Ключові слова: засоби остеосинтезу, переміщення уламків кісток, жорсткість системи фіксаиії переломів, вимірювання переміщень, ичифрове фотографування, придатність методу. 


\title{
Применение цифровой фотосьемки в биомеханических исследованиях систем остеосинтеза
}

\author{
Н.С. Шидловский, А.П. Заховайко, М.М. Дымань
}

\begin{abstract}
Аннотация. Предложенный и экспериментально обоснованный бесконтактный метод измерения смещений отломков костей с помощъю ицфровой фотосъемки. Описанная методика как непосредственного измерения перемещений по меткам, установленным в исследуемых точках в зоне перелома, так и аналитическим методом с положениями реперных точек вне зоны перелома. Приведенные результаты измерений перемещений предложенным методом и традиционным с использованием катетометра. Сопоставление полученных результатов подтвердило эффективность метода измерения смещений отломков костей с помощью ичирового фотографирования для практического применения.
\end{abstract}

Ключевые слова: средства остеосинтеза, перемещения отломков костей, жесткость фиксаиии переломов, измерения перемещений, иифровое фотографирование, пригодность метода.

\section{References}

1. Ковальчук П.Є. Клініко-біомеханічне обгрунтування малоінвазивного блокуючого інтрамедулярного металополімерного остеосинтезу при лікуванні переломів кісток гомілки та їх наслідків: дис. канд. мед. наук.: 14.01.21 / Ковальчук Петро Євгенович; М-во охорони здоров’я України, Буковинська державна медична академія. - Чернівці. 2004. $-158 \mathrm{c}$.

2. Марченкова Н.О. Малоінвазивний остеосинтез при переломах кісточок гомілки: дис. канд. мед. наук.: 14.01.21 / Марченкова Наталія Олексіївна; MO3 України, Тернопільський державний медичний університет ім. І.Я. Горбачевського. - Тернопіль. 2006. - 164 с.

3. Ткачева А.В. Биомеханические системы внешней фиксации при лечении переломов большеберцовой кости: дис. канд. фіз.-мат. наук.: 01.02.08 / Ткачева Ангелина Владимирова; ГОУ ВПО «Саратовский государственный университет им. Н.Г. Чернышевского». - Саратов. 2006. - 149 с.

4. Експериментальні дослідження засобів остеосинтезу. Кол. авторів / За ред. Шидловського М.С., Лакши А.М., - К.: Ленвіт, 2017. - 277 с.

5. Пат. 68177 Україна, Спосіб вимірювання зміщень уламків кісток людини в експерименті / Шидловський М.С., Радомський О.А., Літун Ю.М., Аксютін А.Г. - № u 2012 00818; заявл. 26.01.2012 ; опубл. 12.03.2012, Бюл. № 5. - 8 с.: іл.

6. Пат. 117085 Україна, Спосіб визначення зміщень уламків кісток в місцях переломів / Шидловський М.С., Заховайко О.П., Димань М.М. - № u 2017 008753; заявл. 27.01.2017 ; опубл. 12.06.2017, Бюл. № 11.

7. Шидловский Н.С. Методы исследования деформационной надежности систем остеосинтеза конечностей человека // Біомедична інженерія, - К: 2011, - № 1. - С. 24-31.

8. Шидловський М.С., Заховайко О.П., Димань М.М. Спосіб визначення переміщень в системах остеосинтезу // В кн.: Матеріали XVII міжнародної науково - технічної конференції «Прогресивна техніка, технологія та інженерна освіта» - 21-24 червня 2016 р., м. Одеса - м. Київ, Україна, - С. 21-22.

9. Шидловський М.С., Турчин А.М., Омельченко Т.М., Димань М.М., Мусієнко О.С. Порівняльні характеристики стабільності різних способів фіксації переломів таранної кістки // Літопис травматології та ортопедії. - № 1-2 (33-34) 2016, с.156-162.

10. ДСТУ ISO/IES 17025:2006 «Загальні вимоги до компетентності випробувальних та калібрувальних лабораторій»

11. Рекомендації з метрологічного забезпечення випробувальних і калібрувальних лабораторій, СТУ - Р УкрАО 913.15:2007, Київ, Виконавчий орган УкрАО, 2017 p, - 101 с. 